\title{
AUNC
}

Zabytkoznawstwo i Konserwatorstwo XLVII

Toruń 2016

DOI: http://dx.doi.org/10.12775/AUNC_ZiK.2016.008

\section{Autoportret artystki w polskiej grafice na tle wizerunków własnych graficzek europejskich i amerykańskich z lat dwudziestych-trzydziestych XX wieku}

\section{KATARZYNA KULPIŃSKA}

Zakład Historii Sztuki Nowoczesnej, Wydział Sztuk Pięknych, UMK w Toruniu

e-mail: catalina@umk.pl

Key words: art of the interwar period, graphic arts, self-portrait, woodcut, wood engraving, etching, drypoint, lithograph, Wiktoria Goryńska, Janina Giedroyć-Wawrzynowicz, Wanda Komorowska, Margarete Kubicka, Else Meidner, Margarete Hammerschlag, Marie Laurencin, Mabel Dwight, Wanda Gag, Minna Citron, Peggy Bacon, Hanna Dallos

Słowa kluczowe: sztuka dwudziestolecia międzywojennego, grafika artystyczna, autoportret, drzeworyt, akwaforta, suchoryt, litografia, Wiktoria Goryńska, Janina Giedroyć-Wawrzynowicz, Wanda Komorowska, Margarete Kubicka, Else Meidner, Margarete Hammerschlag, Marie Laurencin, Mabel Dwight, Wanda Gag, Minna Citron, Peggy Bacon, Hanna Dallos

\begin{abstract}
The article discusses self-portraits by Polish female graphic artists created during the interwar period in relation to self-images by female graphic artists native of Germany, France, Britain and the US created within the same period. The issues discussed here include different concepts of self-creation and diverse features of self-portrait manifested in the works by modern women (a manifesto, a mask, an intimate diary, introspection, an image for posterity, and a self-caricature). Graphic self-portraits created by women mirror the awareness of their own identity and professional status. Further, self-portraits have become a witness to ideological changes and the new position of females in socio-political life. Additionally, the research on a self-portrait as an element of one's autobiography is addressed here.
\end{abstract}




\begin{abstract}
Abstrakt
Artykuł dotyczy autoportretów polskich graficzek wykonanych w dwudziestoleciu międzywojennym w odniesieniu do wizerunków własnych tworzonych przez graficzki niemieckie, francuskie, brytyjskie i amerykańskie z tego samego okresu. Omówione zostały różne koncepcje autokreacji i zróżnicowane funkcje autoportretu w twórczości nowoczesnych kobiet (manifest, maska, dziennik intymny, introspekcja, wizerunek dla potomnych, autokarykatura). W graficznym autoportrecie tworzonym przez kobiety odzwierciedlona została świadomość własnej tożsamości i statusu zawodowego; autoportret stał się także świadectwem światopoglądowej przemiany i nowego miejsca kobiet w życiu społeczno-politycznym. Przedmiotem badań jest także autoportret jako element autobiografii.
\end{abstract}

Różnorodność funkcji, jakie może pełnić autoportret (manifest, maska, alter ego, dziennik intymny, introspekcja), wielość intencji i impulsów, pod wpływem których powstaje wizerunek własny ${ }^{1}$ pozwalają założyć, że gatu-

1 Na gruncie polskim badania autoportretu zwieńczone dwiema monografiami i artykułem prowadził Mieczysław Wallis: zob. Mieczysław Wallis, „Autoportrety artystek”, Wiedza i Życie 10 (1949): 916; Mieczysław Wallis, Autoportret (Warszawa: WAiF, 1964); Mieczysław Wallis, Autoportrety artystów polskich (Warszawa: WAiF, 1966). Por. Alina Kowalczykowa, Świadectwo autoportretu (Warszawa: Biblioteka WWSH, Fundacja Humanistyczna, IBL PAN, 2008) - badaczka literatury nawet w rozdziale dotyczącym wizerunków własnych kobiet („Zniewolenie i próby buntu - czyli autoportrety kobiet”) nie porusza kwestii autoportretów polskich artystek Dwudziestolecia. O autoportretach kobiet w malarstwie tego okresu zob. Joanna Sosnowska, Poza kanonem. Sztuka polskich artystek 1880-1939 (Warszawa: IS PAN, 2003); Iwona Luba, Dialog nowoczesności z tradycja (Warszawa: Neriton, 2004). Literatura obcojęzyczna na temat autoportretu, w szczególności tworzonego przez artystki, jest obszerna; zob. Marsha Meskimmon, The Art of Reflection. Women Artists' Self-Portraiture in the Twentieth Century (New York: Columbia University Press, 1996); Frances Borzello, Seeing Ourselves: Women's Self-Portraits (London: Thames \& Hudson, 1998); Frances Borzello, A World of Our Own. Women as Artists (London: Thames \& Hudson, 2000); Liz Rideal, Mirror, Mirror. Self-Portraits by Women Artists (with Essays by Whitney Chadwick and Frances Borzello) (London: Watson-Guptill Publications, 2002); Paula Birnbaum, Women Artists in Interwar France: Framing Femininities (Farnham-Burlington: Routledge, 2011). Warto dodać, że zainteresowanie twórczością graficzną kobiet, niezależnie od epoki, w której powstała, nasiliło się w latach 70.-80. XX w. (choć już w 1901 r. w Nowym Jorku zorganizowano wystawę drzeworytów, akwafort i litografii autorstwa kobiet) i trwa do dziś. Jego efektem są liczne publikacje, głównie anglojęzyczne; zob. Barbara Ann Taylor, "Wood Engraving by Women Artists”, Oxford Art Journal 3 (1980) 1: 79-82; Richard S. Field i Ruth E. Fine, A Graphic Muse: Prints by Contemporary American Women (New York: Hudson Hills, 1987); Patricia Jaffe, Women Engravers (London: Virago, 1988); Elisabeth Harvey-Lee, Mistress of the Graphic Arts: Famous and Forgotten Women Printmakers, c. 1550 - c. 1950 (Dealer's Catalogue) (Oxford: Elisabeth Harvey-Lee, 1995); Elisabeth Harvey-Lee, The Artist Mirrored. A Selection of Artists' Printed Portraits \& Self-Portraits (North Aston: Elisabeth Harvey-Lee, 2002); por. wystawy, np. "Printing Women: Three Centuries of Female Printmakers, 1570-1900" (New York Pu- 
nek ten rozkwitł w odrodzonej Polsce, w okresie eksplozji nowych idei, doświadczeń i talentów. Teza ta znajduje w pełni potwierdzenie w twórczości mężczyzn: malarzy, rzeźbiarzy, grafików ${ }^{2}$ - zarówno wielkich indywidualistów, intrygujących osobowości, ekscentryków, jak i twórców pozostających w cieniu. Natomiast w dorobku polskich artystek okresu międzywojennego odnajdziemy niewiele autoportretów ${ }^{3}$, a wśród nich zaledwie kilka wykonanych w technikach grafiki warsztatowej; tylko na jednym (z zachowanych) artystka przedstawiła siebie w pracowni. Tym samym w polskiej grafice brakuje wyrazistego zdefiniowania roli artystki w społeczeństwie, bo siła autoportretów „zawodowych”, jak zauważa Marsha Meskimmon, polega także na tym, że potwierdzają one aktywność kobiety jako twórczyni kultury: „tworząc takie 'zawodowe' autoportrety kobiety potwierdzały swój profesjonalizm i, w niektórych przypadkach, ekonomiczną niezależność”4. Autoportretów polskich graficzek jest zastanawiająco niewiele - i to zarówno w stosunku do liczebności i różnorodności powstałych w latach dwudziestych i trzydziestych malarskich oraz graficznych wizerunków własnych mężczyzn (także tych zawodowych: w pracowni, z atrybutami profesji malarza i grafika), jak i wykonanych w różnych technikach malarskich i graficznych przez artystki niemieckie, francuskie, amerykańskie. Nasuwa się więc pytanie, czym należy tłumaczyć niemal zupełny brak autoprezentacji artystek polskich, które właśnie w dwudziestoleciu międzywojennym na niespotykaną do tej pory skalę zaczęły profesjonalnie uprawiać grafikę? ${ }^{5}$ Można by założyć, że grafika arty-

blic Library, October 2nd, 2015 - May 27th, 2016); “Unseen Hands: Women Printers, Binders, and Book-Designers" (Princeton University Library, 2005), http://libweb2.princeton. edu/rbsc2/ga/unseenhands/ occupation.html\#5 (dostęp 5 września 2016).

2 W Polsce zainteresowanie autoportretem wykonanym w technikach grafiki warsztatowej zapoczątkowali członkowie grupy Bunt. Większość wybitnych polskich grafików działających w tym czasie ma w dorobku co najmniej jeden, a niektórzy wiele autoportretów wykonanych w różnych technikach graficznych (m.in. Leon Wyczółkowski, Władysław Skoczylas, Wacław Wąsowicz, Ludwik Tyrowicz, Jan Wojnarski, Konstanty Brandel, Wojciech Weiss, Stefan Mrożewski, Jerzy Hoppen).

3 Zwróciła na to uwagę Sosnowska, Poza kanonem, 212, a także Maria Zientara, „Artystki polskie i ich sztuka w latach 1900-1939”, cz. 4 „Przedstawicielki realizmu”, Krzysztofory. Zeszyty Naukowe Muzeum Historycznego Miasta Krakowa 29 (2011): 350.

4 Meskimmon, Art of Reflection, 28.

5 Absolwentki Akademii Sztuk Pięknych w Warszawie i Krakowie, Wydziału Sztuk Pięknych Uniwersytetu Stefana Batorego w Wilnie, Wydziału Grafiki Państwowej Szkoły Sztuk Zdobniczych i Przemysłu Artystycznego (PSSZiPA) w Poznaniu, Wydziału Grafiki PSSZiPA w Krakowie, kursów graficznych prowadzonych przez Ludwika Tyrowicza we Lwowie. Liczba artystek polskich (w tym pochodzenia żydowskiego), które po ukończeniu studiów/nauki w wymienionych jednostkach uprawiały grafikę (i wystawiały swe prace graficzne), zbliża się do stu. 
styczna jako nowy dla nich rodzaj wypowiedzi stanowiła obszar prób i poszukiwań. Jednak, co na zwróciła uwagę Joanna Sosnowska ${ }^{6}$, niewielka jest także liczba malarskich autoportretów polskich artystek z tego czasu, co przeczy owej tezie. Być może zmiana statusu kobiet w odrodzonej Polsce, prawa, które gwarantowała im konstytucja i realne możliwości, które uzyskały, na tyle umocniły ich pozycję, że nie uważały już za konieczne samookreślenia się jako twórczynie i kobiety za pomocą swego zawodowego wizerunku - swego rodzaju „wizytówki”. Poza tym większość z nich równolegle zajmowała się, oprócz grafiki, kilkoma innymi dziedzinami ${ }^{7}$, i to nie tylko artystycznymi. Ponieważ działały jednocześnie i z równym zaangażowaniem na wielu obszarach aktywności - zawodowej, społeczno-organizacyjnej i domowej, nie identyfikowały się wyłącznie z jedną dyscypliną, w tym przypadku grafiką artystyczną. Podejście polskich twórczyń zmieniło się po 1945 roku, czego świadectwem są grafiki, na których przedstawiają siebie z atrybutami właściwymi dla warsztatu danej techniki graficznej.

Obszerne zagadnienie autoportretu artystek w grafice europejskiej i amerykańskiej lat międzywojennych XX wieku zostanie w tym artykule jedynie wstępnie rozpoznane ${ }^{8}$. Punktem wyjścia były autoportrety w twórczości polskich graficzek, jednakże ze względu na ich niewielką liczbę i specyfikę poszczególnych ujęć wymagały porównania z wizerunkami własnymi graficzek z innych krajów. Problematyka ta nie była do tej pory przedmiotem szerzej zakrojonych badań. Autoportrety Wandy Komorowskiej powstałe jeszcze przed 1910 rokiem omówiła Irena Kossowska9 : w monografii poświęconej

6 Sosnowska, Poza kanonem.

7 Najczęściej uprawiały równolegle malarstwo lub ilustrację, tkaninę artystyczną, fresk. Kilkanaście pracowało jako nauczycielki na etatach w szkołach podstawowych i średnich (także zawodowych). Były też wśród nich publicystki, działaczki, dla których aktywność społeczna była równie istotna jak sztuka. Autorka przebadała kilkadziesiąt biografii artystek zajmujących się grafiką lub (obok malarstwa) także grafiką. Znaczna część prezentowanych tu wniosków dotyczących grafiki artystycznej uprawianej przez nie w okresie międzywojnia jest oparta na analizie dokumentów osobistych i materiału ikonograficznego przedstawionej w przygotowanej do druku książce, zob. Katarzyna Kulpińska, Matryce, odbitki - ślady kobiet. Polskie graficzki i ich twórczość $w$ dwudziestoleciu międzywojennym (Toruń: Wydawnictwo Naukowe UMK, 2017).

8 Graficzne autoportrety polskich artystek szerzej omówiłam w zapowiedzianej książce poświęconej polskim graficzkom i ich twórczości w dwudziestoleciu międzywojennym (Kulpińska, „Matryce”).

9 Irena Kossowska, Narodziny polskiej grafiki artystycznej 1897-1917 (Kraków: Universitas, 2000); Irena Kossowska, „Aporia: zwielokrotnione wizerunki, sparafrazowane obrazy”, Konteksty 1-2 (2012): 285-297. 
młodopolskiej grafice określiła je jako inspirowane grafikami Whistlera, natomiast w artykule z 2012 roku, gdzie analizowała domniemany autoportret Komorowskiej (z lat około 1906-1910), zwróciła uwagę na jego ambiwalentny charakter i odmienne tropy interpretacyjne. Spośród autoportretów wykonanych w technikach grafiki warsztatowej przez polskie artystki międzywojnia najczęściej był omawiany drzeworyt Autoportret ze słuchawką telefonu Wiktorii Goryńskiej ${ }^{10}$ (zarówno w publikacjach na temat polskiej grafiki, stylu art déco, jak i twórczości kobiet); autoportret Janiny Giedroyć-Wawrzynowicz doczekał się zaledwie wzmianek w artykułach i katalogach wystaw ${ }^{11}$.

Autorką pierwszego autoportretu w grafice polskiej XX wieku była Wanda Komorowska (1873-1946), która jeszcze w okresie młodopolskim wykonała intrygujące wizerunki własne ${ }^{12}$ : Autoportret (akwaforta) z około 1910 roku i Dwie kobiety/Autoportret przed lustrem (akwatinta barwna) z około 1906 roku. Dostrzegając podobieństwo rysów, zaryzykowałabym twierdzenie, że Komorowska ukazała swoją twarz także w akwaforcie z akwatintą Przyjaciółki (około 1906 r.) - wyłaniającą się na drugim planie zza profilu kobiety w koku. Nietypowy jest sposób ujęcia obu postaci, bo popiersie kobiety wyeksponowanej na pierwszym planie pozostaje dla widza obojętne, „nie domaga się” ona reakcji, natomiast widoczna za nią twarz drugiej kobiety zabiega o uwagę widza spojrzeniem i zagadkowym uśmiechem. Grafika ta w zbiorach Muzeum Narodowego we Wrocławiu nosi tytuł Przyjaciółki, w monografii I. Kossowskiej $^{13}$ zaś występuje pod tytułem Dwie głowy i datowana jest na około 1906 roku. Komorowska skupiając się na wnętrzach oraz statycznych, pogrążo-

10 Wallis, „Autoportrety artystek”, 916; Wallis, Autoportret; Wallis, Autoportrety artystów; Wiktoria Goryńska 1902-1945, oprac. Maryla Sitkowska (Warszawa: Muzeum Narodowe, 1977); Artystki polskie, Muzeum Narodowe w Warszawie, koncepcja, wstęp i red. Agnieszka Morawińska (Warszawa: Muzeum Narodowe, 1991); Wyprawa w Dwudziestolecie, red. Katarzyna Nowakowska-Sito (Warszawa: Muzeum Narodowe, 2008); Dialog czarno na białym. Grafika polska i węgierska 1918-1939, Muzeum Narodowe w Warszawie - Magyar Nemzeti Galéria w Budapeszcie, tekst Anna Manicka i Katalin Bakos (Warszawa: Muzeum Narodowe, 2009); Sosnowska, Poza kanonem; Regina Stawska, „Między rylcem a floretem”, Art\&Business 11 (2005): 28-31; Zientara „Artystki polskie”, 327-362.

11 Wydobyć z zapomnienia, red. Jacek Bochiński i Janusz Plapis, tekst Róża Wawrzynowicz-Bilip (Warszawa: Muzeum Historyczne st.m. Warszawy [2008]); Regina Stawska, „Graficzka nieznana”, Art\&Business 10 (2008): 66-69; Joanna Stacewicz, „Mała rewolucja i wielkie serce. Kontrastowo o Janinie Róży Giedroyć-Wawrzynowicz", Aspiracje wiosna (2009): 48-53; Sztuka wszędzie. Akademia Sztuk Pięknych w Warszawie 1904-1944, koncepcja Maryla Sitkowska, red. Jolanta Gola, Maryla Sitkowska i Agnieszka Szewczyk (Warszawa: ASP, 2012).

12 Były one przedmiotem badań, zob. Kossowska, Narodziny; Kossowska, „Aporia”, 285-297.

13 Kossowska, Narodziny. 
nych w zadumie postaciach i relacjach między nimi, powtarzała określone typy postaci, najczęściej dzieci i starców, natomiast urozmaicała sposoby ujęcia (przez motyw lustra lub drzwi otwartych na dalsze pomieszczenia). Jak wspominała jej siostrzenica, Anna Moeser ${ }^{14}$, artystka nie miała wielu modeli. Nie założyła własnej rodziny, mieszkała samotnie oddana całkowicie swej pracy; zapewne była dla siebie najlepszą modelką. W późniejszych autoportretach, wykonanych w dwudziestoleciu międzywojennym, Komorowska ukazała siebie jako kobietę w wieku około sześćdziesięciu-siedemdziesięciu lat, w okularach o okrągłych drucianych oprawkach i skromnej fryzurze, odzianą w ciemny strój, twarzą zwróconą w stronę widza; jej dłonie, które dla przedstawionej tu sceny zdają się mieć kluczowe znaczenie, wykonują tajemniczy gest przypominający odliczanie na palcach. Enigmatyczną wymowę kompozycji wzmaga lekki uśmiech artystki i jej wyraziste, choć częściowo ukryte za oprawkami okularów spojrzenie. Intrygujący taniec palców jest inny w mezzotincie Autoportret $I I^{15}$ - palce uniesionej prawej dłoni jakby przebiegają po niewidzialnych klawiszach, lekkie, sprawne, ruchliwe, co w zawodzie graficzki ma niebagatelne znaczenie. Komorowska uzyskuje miękkie półtony w partii bruzd i zmarszczek na twarzy, wydobywa silne cienie. Oba autoportrety świadczą o uważnym studiowaniu własnej fizjonomii i uchwyceniu oznak upływającego czasu. W porównaniu z zadumanym, sennym Autoportretem z około 1910 roku oba wizerunki własne z późnych lat dwudziestych przekonują o żywotności i energii graficzki, mimo bruzd na twarzy, które wskazują na upływ lat i bagaż doświadczeń.

Wśród polskich graficzek działających w Dwudziestoleciu najwięcej autoportretów wykonała Wiktoria Goryńska (1902-1945). Dorastała ona i kształciła się w Wiedniu i Londynie, w latach 1923-1927 studiowała w warszawskiej Akademii Sztuk Pięknych, należała do Rytu. Wszystkie zachowane ${ }^{16}$ do dziś autoportrety Goryńskiej cechuje niekonwencjonalność ujęcia. Artystka pozornie jest skupiona na własnej powierzchowności i prezentacji jako ko-

14 Zakład Narodowy im. Ossolińskich, rkps sygn. 17186/II, k. 231-235, Materiały do biografii i twórczości lwowskich artystów grafików dwudziestolecia międzywojennego zebrane przez Irenę Rylską, List A. Moeser do I. Rylskiej.

15 Według I. Rylskiej został wykonany przed 1928 r., choć jest to nieco zmodyfikowana wersja autoportretu wyżej omówionego. Zob. Irena Rylska, Katalog zbiorów Gabinetu Grafiki, t. 1 Grafika polska w latach 1901-1939 (Wrocław: Muzeum Narodowe, 1983).

16 Z katalogu wystawy graficzki w Zachęcie (1939) wiadomo, że wykonała jeszcze jeden autoportret w drzeworycie (kolorowanym) w 1935 r. Nie znalazłam żadnej jego odbitki ani reprodukcji. 
biety pewnej siebie, otwartej na świat (Autoportret w stroju domowym, 1929), nowoczesnej (Autoportret z telefonem, 1930), wysportowanej (Autoportret jako florecistka, 1932-1935) i pełnej wiary (w „asystencji” Matki Boskiej szermierzy). Takiemu odczytaniu wizerunków sprzyjają wypowiedzi jej przyjaciół: „Wiktoria była dziewczyną na wskroś nowoczesną, ale w tym najlepszym słowa znaczeniu. Wyróżniały ją szerokie zainteresowania i poczucie odpowiedzialności. Była przy tym bardzo niezależna. [...] We wszystkim była sobą, osobą niepowtarzalną. Przy tym jej osobowość wyróżniała się jednorodnością. Zainteresowania, pasje, czyny, sposób mówienia, ruchy, nawet ubiór były wzajemnie powiązane, integrujące nawet cechy jakby od siebie odległe" ${ }^{17}$. Jednak biorąc pod uwagę jej biografię, analizując rodzaje aktywności na różnych etapach życia i podkreślaną przez osoby bliskie Goryńskiej jej religijność, można się spodziewać, że w interpretacji tych autoportretów mogłaby być pomocna psychoanaliza. Próba odpowiedzi na pytanie, czy jest to świadoma autokreacja, za którą artystka skrywa głębsze przeżycia, przysparza pewnych problemów. Wprawdzie dane biograficzne dotyczące jej życia zawodowego i aktywności w sferze publicznej są pełne, lecz nie dysponujemy prawie w ogóle wypowiedziami Goryńskiej ${ }^{18}$, które pozwoliłyby na poznanie jej poglądów i przekonań oraz mogłyby rzucić światło na jej życie prywatne ${ }^{19}$. „Wiele oblicz”, a raczej jungowskich person, które Goryńska prezentowała otoczeniu, różnorodność kontekstów, w których umieszczała swą postać w autoportretach, wyznacza pewne etapy życia artystki. Najwcześniejszy określają humorystyczne rysunki - scenki rodzajowe, w których ukazuje siebie jako jedną z bohaterek. $Z$ autoportretów graficznych wykonanych przez dojrzałą już artystkę znamy kilka.

Na Autoportrecie w stroju domowym Goryńska przedstawiła siebie (w ujęciu całopostaciowym) jako pełną życia, energii, nieco kokieteryjną, a jednocześnie zadziorną młodą kobietę. O takim wrażeniu decyduje poza, ale także

17 Opinia Wandy Telakowskiej, koleżanki Goryńskiej ze studiów. Zob. Wiktoria Goryńska, 7-8. Obraz Goryńskiej jako niezależnej i wiernej swym zasadom indywidualistki, przy tym osoby skromnej, zdolnej do poświęceń, wyłania się także z innych opinii (których nie ma zbyt wiele), zob. m.in. Wacław Borowy, „Wspomnienie o Wiktorii Goryńskiej”, Tygodnik Powszechny, 21-28 maja 1950, 7.

18 Poza nielicznymi zdystansowanymi komentarzami do własnej twórczości w artykułach w prasie zagranicznej, zob. Wiktoria Julia Goryńska, "Contemporary Wood-Engraving in Poland”, The Print Collector's Quarterly 22 (1935): 325-347.

19 W tym zakresie niezwykle pomocne okazały się informacje rodziny, choć poza kilkoma wyjątkami nie mają one wartości bezpośredniej relacji. 
wyraz jej twarzy - śmiałe spojrzenie ciemnych oczu, lekko uniesione kąciki ust. Wnętrze, w którym stoi na tle kwiecistych zasłon z gęstym deseniem egzotycznych kwiatów i liści, na miękkim, puszystym dywanie, jest przytulne, a tkaniny podkreślają intymny nastrój. Goryńska nie jest tu artystką, lecz przede wszystkim kobietą i eksponuje swą kobiecość przyjmując męski punkt widzenia $^{20}$. Ukazuje siebie jako obiekt oglądu w zmysłowo-kokieteryjnej pozie. Jednocześnie spojrzeniem rzuca wyzwanie i przyjmuje postawę zaczepną. W kolejnych swoich wizerunkach pokazała się od zupełnie innej, emocjonalnie „chłodnej” strony, pełnej dystansu. Autoportret w stroju domowym (1929) i Autoportret $z$ telefonem (1930), tak nieodległe czasowo, dzieli jednak dzieli przepaść w sposobie autoekspresji. Choć oba ujęcia są kameralne, wskazują na zupełnie inne aspekty osobowości i płaszczyzny doświadczeń życiowych. Z kobiety, która chce się podobać Goryńska staje się aktywną działaczką oddaną służbie obywatelskiej. Zalotność i manifestacja urody na pierwszym z autoportretów nie mają racji bytu w drugim. Ubiór i fryzura silnie akcentują tę przemianę wewnętrzną - strój domowy w autoportrecie z 1929 roku i naturalne falowanie włosów, luźne kosmyki grzywki zamieniają się w drugim w kanciaste, zgeometryzowane linie grzywki i strzyżenia nad karkiem. Drugi wizerunek jest wyraźnie maskulinizowany, a formalnie poddany delikatnej, lecz zauważalnej geometryzacji w stylu art déco. W tej pracy (i w autoportrecie przedstawiającym ją jako florecistkę) artystka zdecydowała się na ujęcie do pasa, z profilu, eksponując charakterystyczną linię orlego nosa i modnie przystrzyżone gęste włosy. Skupiona, nie odsłania emocji, a widz może ją jedynie poddać oglądowi - niedostępną, zatopioną w rozmowie. Jest tu uosobieniem kobiety nowoczesnej, wyemancypowanej, ale także skoncentrowanej na własnym rozwoju, zarówno duchowym, intelektualnym, jak i fizycznym; wizerunek ten jest jednocześnie świadectwem epoki, przemian w mentalności i sposobie życia kobiet po pierwszej wojnie światowej. Autoportret jako florecistka (drzeworyt, około 1932-1935) jest unikatowym przykładem identyfikowania się z elitarną, wcześniej dostępną tylko dla mężczyzn dyscypliną sportową ${ }^{21}$. Wydaje się manifestem - Goryńska była jedną z pierwszych

20 Por. Clive Owens, „Dyskurs Innych: feministki i postmodernizm”, tłum. Małgorzata Sugiera, w: Postmodernizm. Antologia przekładów, oprac. i wstęp Ryszard Nycz (Kraków: Wydawnictwo Baran i Suszczyński, 1997), 425.

21 Goryńska odgrywała ważną rolę w strukturach Polskiego Związku Szermierczego; wchodziła w skład zarządu, w latach 1934-1936 prowadziła Referat Spraw Kobiecych, uczestniczyła w pracach komisji sportowej, dyscyplinarnej i propagandowej, miała także uprawnienia do sędziowania. 
Polek uprawiających szermierkę. W tym drzeworycie przedstawia siebie na pierwszym planie, na tle ćwiczących kolegów, w ujęciu do pasa, a jej sylweta zajmuje niemal cały kadr leżącego prostokąta. Zastanawia koncepcja ukazania siebie jako sylwety-cienia na tle jasnego parawanu. Wzniesiony floret w prawej dłoni i maska pod pachą, charakterystyczna fryzura współtworzą obraz energicznej, pewnej siebie kobiety, chociaż jest też uchwytna nuta heroizmu w jej postawie ${ }^{22}$.

W grafice Goryńskiej można odnaleźć jeszcze inne, ukryte autoportrety. Uwidoczniła siebie w stroju szermierczym wśród innych osób w Madonnie szermierzy - i wraz z kilkoma sportowcami adoruje Matkę Boską w asyście świętych patronów. W Szermierce, drzeworycie z 1934 roku, jest jedną z kobiet spoglądających z loży na matę. Zagadkowy portret z 1929 roku²3, określany w literaturze ${ }^{24}$ jako autoportret, omawiam szerzej w oddanej do druku książce poświęconej dorobkowi polskich graficzek dwudziestolecia międzywojennego. Goryńską, według słów Telakowskiej, wyróżniały na tle jej rówieśników „poważne zainteresowania intelektualne, zdyscyplinowanie i konsekwencja, porządkujące nawet stany emocjonalne”25 - i ta opinia wydaje się kluczowa dla określenia postawy artystki i w życiu, i sztuce: przedkładanie intelektu, woli i działania na rzecz innych nad uczucia, emocje i sprawy prywatne. Różne „wcielenia” w autoportretach Goryńskiej oddają bogactwo cech jej charakteru (zalotna i śmiała w stroju domowym, posągowa jako florecistka, religijna i oddana Matce Boskiej w Madonnie szermierzy). Niekiedy tylko w symbolice motywów, sposobie określenia relacji między nimi dochodzi do głosu stłumiona emocjonalność.

Janina Róża Giedroyć-Wawrzynowicz, absolwentka warszawskiej Akademii Sztuk Pięknych, malowała, projektowała i tkała kilimy, wykonywała ilustracje i uprawiała grafikę. Oprócz kilku akwarelowych i olejnych autoportretów (m.in. Autoportret w błękitnej chustce, 1926; Autoportret w czarnym fartuchu malarskim; Autoportret okupacyjny) stworzyła także swoje portrety w drzeworycie odbijanym według własnej metody białą farbą na czarnym

${ }^{22}$ W tym autoportrecie Goryńska wydaje się mieć wiele wspólnego z Joanną d’Arc z cyklu drzeworytów z 1927 r. i późniejszej luźnej ryciny Joanna d’Arc z 1929 r.

23 Mowa o Głowie kobiety (wyraźnie starszej od artystki w momencie tworzenia portretu), wyłaniającej się z czarnego tła odbitki. Zbliżone ujęcie i rysy twarzy widnieją na innym drzeworycie Goryńskiej (Głowa na poduszce).

24 Maria Grońska, Nowoczesny drzeworyt polski (Wrocław: Ossolineum, 1971), 179; Wiktoria Goryńska, 36.

25 Wiktoria Goryńska, 7. 
papierze ${ }^{26}$. Autoportret $w$ owalu z około 1932 roku powstał w dwóch wersjach (na papierze czarnym i niebieskim żeberkowym) właśnie metodą „biało na czarnym”. Artystka nadała mu formę charakterystyczną dla miniatur noszonych w medalionach. To wizerunek kobiety trzydziestoletniej, choć artystka wygląda znacznie młodziej, wręcz dziewczęco. O takim wrażeniu decyduje fryzura z przedziałkiem pośrodku głowy, falującymi kosmykami po obu stronach twarzy i ciężkim węzłem włosów spiętych na karku. Wyrazisty wizerunek odbity białą farbą na czarnym papierze zupełnie nie przypomina wcześniejszej odbitki na papierze żeberkowym niebieskim, całkowicie pozbawionej elementów tła zaznaczonego w odbitce na czarnym papierze. Autoportret ze sztalugami powstał około 1933 roku, u progu samodzielnego, dorosłego życia graficzki, niemal rok po otrzymaniu dyplomu ASP i ukończeniu kursów dla nauczycieli rysunku oraz rok przed ślubem. Jest jednym z nielicznych wówczas w sztuce polskiej, a w grafice tego czasu jedynym autoportretem „mistrzyni w pracowni” - przy czym jest to pomieszczenie niemal puste, bardzo skromne. Janina Giedroyć ujęła siebie na pierwszym planie na wprost, w popiersiu, na tle sztalug. Ten atrybut o kluczowym znaczeniu, gdy twórca portretuje się przed sztalugami w trakcie pracy, odgrywa w tym wizerunku niewielką rolę - pozostaje na dalszym planie, za plecami artystki. Twórczość nie determinuje jej wyborów jako jednostki, tylko ją dookreśla, wzbogaca. Artystka z niedbałą fryzurą i w codziennym odzieniu ujęła siebie bardzo „blisko” widza, patrzy wprost na niego. Tę bezpośrednią prezentację, śmiałą w swej bezpretensjonalności, pogłębia metoda „zamiany” czerni i bieli na odbitce drzeworytu. Czarny papier tworzy naturalną optyczną ramę, a biel farby - co staje się widoczne podczas dokładniejszego oglądu - nie kryje papieru jednolicie, odsłaniając na powierzchni równomierne, drobne prześwity podłoża $\mathrm{a}^{27}$. Jest znamienne, że oba autoportrety graficzne wykonane zostały własną metodą artystki, co było, jak celnie podkreśliła Joanna Stacewicz, „wyraźnym znakiem pełni twórczej dojrzałości” ${ }^{28}$, jaką w owym czasie osiągnęła Janina Giedroyć-Wawrzynowicz.

\footnotetext{
${ }^{26}$ O jej „wynalazku” pisała z uznaniem zagraniczna prasa, w polskiej przeszedł niemal bez echa; por. Kulpińska, „Matryce”.

${ }^{27}$ Znanych jest kilka odbitek tego drzeworytu (zbiory prywatne i Muzeum Akademii Sztuk Pięknych w Warszawie).

28 Stacewicz, „Mała rewolucja”, 50.
} 
Warto jeszcze wspomnieć o autoportrecie Zofii Bajdo ${ }^{29}$ : wykonała go w akwaforcie na trzecim roku studiów (1935) w krakowskiej Akademii Sztuk Pięknych. Swą twarz ujęła w dużym zbliżeniu; uwagę widza przyciągają duże oczy młodej artystki, długie łuki brwi i zalotne spojrzenie skierowane w górę, przy pochylonej głowie. Fotografia Zofii Bajdo zamieszczona w aktach studentów krakowskiej ASP ${ }^{30}$ upewnia o podobieństwie, jednak twórczyni wyolbrzymiła te elementy fizjonomii, które czynią ją podobną do Marii Pawlikowskiej-Jasnorzewskiej. Nie mamy jednak pewności, że był to efekt zamierzony.

Liczne są rysunkowe i linorytnicze autoportrety Margarete (z domu Schuster) Kubickiej, Niemki, członkini poznańskiej grupy ekspresjonistów Bunt. Stanowią one przenikliwe studium własnej twarzy, poddanej niekiedy geometryzacji i uproszczeniu, wyróżniające się ekspresją oczu. Badaczka twórczości Kubickich, Lidia Głuchowska przeanalizowała wizerunki własne tej artystki ${ }^{31}$, a ja wspomniałam o nich w artykule Autoportret $w$ grafice artystów grupy Bunt ${ }^{32}$. Układają się one w swoisty dziennik życia, analogicznie do praktyki Käthe Kollwitz. Dla Kollwitz autoportret był jedną z ważniejszych form wypowiedzi - uprawiany od wczesnej młodości do późnej starości ${ }^{33}$ stał się zapisem upływającego czasu, świadectwem życiowych dramatów i obsesji artystki, swoistym pamiętnikiem zatrzymującym chwile i odzwierciedlającym stany emocjonalne.

Wśród autoportretów graficzek szczególnie interesujące są te, na których artystki ukazują siebie w pracowni lub z narzędziami właściwymi dla różnych technik graficznych (dłutko, rylec, igła, kredka litograficzna), w trakcie opracowywania matrycy lub z prasą graficzną. Są one potwierdzeniem zawodowej tożsamości, a sposób ukazania własnej postaci wiele mówi o stosunku artystki do grafiki (pasja, wyzwanie lub po prostu zadanie do wykonania). Brakuje takich autoportretów w twórczości polskich graficzek, natomiast często portretowały się w tej roli artystki amerykańskie.

29 Urodzona w 1912 r., studiowała malarstwo i rzeźbę pod kierunkiem Władysława Jarockiego od roku akademickiego 1931/1932.

30 Archiwum ASP w Krakowie, Rodowody 1929-1934, sygn. T 21 B, A 78, teka 1931/1932.

31 Por. Lidia Głuchowska, Avantgarde und Liebe. Margarete und Stanislaw Kubicki 1910-1945, Serie: Humboldt-Schriften zur Kunst- und Bildgeschichte, 4 (Berlin: Gebr. Mann, 2007), 100, 327, 355, 366.

32 Katarzyna Kulpińska, „Autoportret w grafice artystów grupy Bunt”, w: Bunt a tradycje grafiki w Polsce i Niemczech, (Bydgoszcz: Muzeum Okręgowe, 2015), 61-74.

33 Autoportrety tworzyła od 1885 r.; jeden z ostatnich wykonała w litografii w 1941 r. 
Mabel Dwight (1876-1955) w litograficznym Autoportrecie z 1932 roku przedstawiła siebie podczas szkicowania na metalowej płycie o sfazowanych narożach. Uważnie studiowała swoje odbicie w lustrze - ujęcie jest realistyczne, a przytłumione światło lampy buduje kameralny nastrój miejsca pracy graficzki, sam na sam ze swoimi myślami i dziełem. „Dla autoportrecisty problem tożsamości ma dwa oblicza: autora i modela" ${ }^{4}$ - pisał Philippe Lejeune wskazując na podwójną obecność artysty w autoportrecie: jako osoby przedstawionej i osoby tworzącej. Na odbitce litograficznej Dwight prezentując siebie jako graficzkę nie patrzy na szkic, lecz kieruje spojrzenie nieco w bok, jak gdyby właśnie spoglądała w zwierciadło.

Peggy Bacon (1895-1987) w autoportrecie zatytułowanym Lady Artist (1925, sucha igła) siedzi na krześle w swej pracowni rysując kompozycję na płytce graficznej trzymanej na kolanach. Sposób, w jaki siebie ukazała - włosy upięte w kok, okulary w okrągłych oprawkach, skromna, ciemna sukienka z kołnierzykiem, sznurowane półbuty - czyni z niej „zwykłą” kobietę pracującą. Przez okno, na tle którego się sportretowała, widoczny jest budynek po przeciwnej stronie ulicy i jego mieszkańcy w oknach. Bacon w takim ujęciu pozbawia się statusu jednostki wyjątkowej, obdarzonej talentem - pracuje tak jak inni, jest częścią społeczeństwa, dziewczyną z sąsiedztwa, która obserwuje mieszkańców i sama pozwala na siebie patrzeć w czasie pracy. Pod krzesłem artystki śpi kot, między rysunkami rozrzuconymi w malowniczym rozgardiaszu na podłodze stoi jego miseczka. Sfera domowa łączy się tu z zawodową: przestrzeń, w której przedstawiła siebie graficzka, nosi cechy domowe (prywatne) ${ }^{35}$, ale ma też charakter pracowni. To nakładanie się obszarów można uznać za typowe dla większości graficzek, gdyż niektóre techniki grafiki warsztatowej nie wymagają specjalnego, osobnego miejsca do opracowania matrycy ${ }^{36}$. Możliwość pracy w warunkach domowych, niewątpliwie wygodna, utrwalała jednak status ich twórczości jako hobby, sztuki uprawianej amatorsko, rękodzielniczej, kojarzonej ze znanym od wieków kanonem „zajęć kobiecych” (haftowanie, koronczarstwo, wycinanki itp.). Świadectwem

34 Philippe Lejeune, „Patrząc na autoportret”, w: Philippe Lejeune, Wariacje na temat pewnego paktu. O autobiografii, tłum. Regina Lubas-Bartoszyńska (Kraków: Universitas, 2001), 210.

35 Domowy charakter ma przestrzeń w litografii „Autoportret” („Self-Portrait”) Brytyjki Norah Brookes (ur. ok. 1910 r.): artystka siedzi w fotelu, przy dużym stole, na jego krawędzi opiera szkicownik podczas rysowania; przytulny nastrój podkreślają miękkie tkaniny (kotary, serweta), siedzący obok fotela kot.

36 Klocek drzeworytniczy, płytkę linoleum i metalową (w technikach ciętych) można opracować w warunkach domowych (wiele polskich graficzek w międzywojniu tak pracowało). 
zawodowstwa była własna pracownia - malarki częściej niż graficzki utrwalały swój wizerunek mistrzyń w atelier, rzadziej jednak z modelką/modelem ${ }^{37}$.

Autoportret w pracowni doświetlonej wysokim porte-fenêtre wykonała Minna Citron (1896-1991). Jej Autoekspresja (litografia,1932) jest wizerunkiem zawodowym - graficzka sportretowała siebie w studio na Union Square (w tle widoczny Kleins Departament Store), siedzącą przed sztalugami, podczas szkicowania, w naturalnej, wygodnej pozie (nogi w rozkroku, spod sukienki widoczne spinki od pasa do pończoch i nagie uda). Wizerunek stanowi przykład dystansu wobec siebie i własnego ciała (wiadomo, że Citron kpiła ze swojej tendencji do tycia). Dwa lata później powstała olejna, nieco zmodyfikowana jego wersja. Zupełnie inny jest Autoportret w kapeluszu tej artystki (litografia, 1935), na którym ukazała tylko uśmiechniętą twarz w ujęciu trzy czwarte, potraktowaną w sposób szkicowy. Minna Citron zostawiła wiele autokarykatur rysunkowych, podobnie jak Aline Fruhauf ${ }^{38}$ (1907-1978), jej rodaczka. Fruhauf, karykaturzystka z Nowego Jorku, tworzyła swoje podobizny w ujęciu humorystycznym, zazwyczaj podkreślając nienaturalną długość szyi i przesadnie akcentując pewne fragmenty twarzy, np. mocno zarysowane, podniesione do góry brwi (litografie z 1931 i 1933 roku). Wanda Gág (1893-1946), graficzka, ilustratorka, pisarka, tłumaczka, wykonała liczne autoportrety rysunkowe i graficzne - ze szkicownikiem na kolanach, z kotem na rękach, w swobodnych ujęciach, np. podczas rysowania na szezlongu, w pozie półleżącej. Przedstawiała siebie tak jak prezentuje się na zdjęciach z tego czasu, z charakterystyczną krótką fryzurą i równo przyciętą gęstą grzywką. Riva Helfond (1910-2002) ukazała siebie w Autoportrecie (1939, litografia) siedzącą przed kamieniem litograficznym; ma zamyślony wzrok, policzek wspiera dłonią, jakby zastanawiając się nad kompozycją.

Oprócz autoportretów wyraźnie określających profesję, amerykańskie graficzki przedstawiały się także bez atrybutów zawodu; są to np. studia własnej twarzy (Autoportret Isabel Bishop, akwaforta, 1929). Nietypowy jest wizerunek własny Kyry Markham (1891-1967), która oprócz tego, że uprawiała litografię, była także aktorką teatralną i filmową. Wykonała swój litograficzny

37 Przykładem pionierskie dzieło brytyjskiej malarki i graficzki, pierwszej od 1768 r. członkini Królewskiej Akademii Sztuk Pięknych, Laury Knight (1877-1970) - „Autoportret z aktem” („Self Portrait with Nude”, 1913, olej).

38 Jest autorką wspomnień wydanych w 1990 r., zob. Alina Fruhauf i Erwin P. Vollmer, Making Faces. Memoirs of a Caricaturist Aline Fruhauf (Santa Barbara: John Daniel \& Co, 1990). 
portret we wcieleniu Lady Makbet (1935) w scenicznym oświetleniu, na tle scenografii, w kostiumie granej przez siebie postaci.

Z niemieckich graficzek, oprócz wybitnej Käthe Kollwitz, której dorobek w tym zakresie został opracowany ${ }^{39}$, autoportrety graficzne, rysunkowe i olejne tworzyła Else Meidner (1901-1987). Była uczennicą, a następnie żoną Ludwiga Meidnera i przez długi czas pozostawała w jego cieniu. Dwa warianty Autoportretu $z$ igła akwafortowa (jeden datowany na około 1925 roku, drugi na lata1926-1927) ${ }^{40}$ potwierdzają, że artystka definiowała siebie poprzez uprawianą dyscyplinę. We wcześniejszej wersji wydobywa zarys swej sylwety (popiersie) z nawarstwionych, nakładających się i równoległych nerwowych linii tworzących jaśniejsze i ciemniejsze płaszczyzny. Akcentuje duże, ciemne oczy wpatrzone w lustrzane odbicie i jasne dłonie: prawa zarysowuje formę na metalowej płycie, lewa przytrzymuje matrycę. W późniejszym autoportrecie (suchoryt) graficzka koncentruje się na swym wizerunku dookreślając, a nie tylko sugerując formę - doprecyzowuje szczegóły twarzy i formę fryzury. Także w tej wersji zwracają uwagę przede wszystkim duże ciemne oczy, wnikliwie „badające” odbicie w zwierciadle, oraz ręce: prawa trzymająca igłę akwafortową (widoczny jest tylko fragment), lewa zaciśnięta na wysokości piersi, prawdopodobnie na fragmencie sukni. W wizerunku wykonanym około 1925 roku artystka podkreśla znaczenie gestu, tworzenia, w kolejnym koncentruje się na swej postaci - pozie i mimice twarzy odzwierciedlających stan emocjonalny (przestrach, niepewność?). Autoportrety graficzne i olejne tworzyła Augusta von Zitzewitz (1880-1960); jedną z jej linorytniczych podobizn własnego autorstwa - lapidarną, wyznaczoną kilkoma liniami i plamami - zamieściło na okładce czasopismo „Die Aktion”. Spod ręki Jeanne Mammen ${ }^{41}$ (1890-1976), wnikliwej obserwatorki typów ludzkich, wychodziły w okresie republiki weimarskiej karykaturalne portrety i autoportrety. Artystka, niepozbawiona autoironii, w rysunkowym wizerunku własnym z 1932 roku jest dla

39 M.in. Otto Nagel, Die Selbstbildnisse der Käthe Kollwitz (Berlin: Henschelverlag, 1965); Martha Kearns, Käthe Kollwitz: Woman and Artist (New York: Feminist Press, 1976).

40 Są to prace wykonane już po studiach (w latach 1918-1925 artystka uczęszczała do berlińskiej Kunstgewerbeschule i Kunstakademie). Odbitki w zbiorach Ludwig Meidner-Archiv, Jüdisches Museum der Stadt Frankfurt am Main, prezentowane na stronie muzeum: http:// juedischesmuseum.de/fruehere_ausstellungen.html? \&tx_ttnews[pointer] $=12 \& \mathrm{cHash}=\mathrm{a}-$ 9e70c645e (dostęp 16 kwietnia 2015) oraz http://juedischesmuseum.de/ludwig-meidner-archiv.html (dostęp 16 grudnia 2015).

41 Urodzona w Berlinie, dorastała w Paryżu, gdzie studiowała w Académie Julian, następnie w Brukseli w Académie Royale des Beaux-Arts, a w 1911 r. w Scuola Libera Academica w Rzymie. W 1916 r. wraz z rodziną wróciła do Berlina. 
siebie bezlitosna. Wydobywa ze swej fizjonomii i sylwetki cechy, które współtworzą obraz kobiety nieurodziwej, zgorzkniałej, pełnej nieukrywanej złości. Takie wrażenie sprawia postawa (lekko przygarbiona z ramionami wysuniętymi do przodu) i sposób ukazania twarzy (długi nos, zaciśnięte usta, przymrużone oczy). W odmienny sposób podeszła do zadania ekspresjonistka Trude Brück $^{42}$ (1902-1992): na Autoportrecie wykonanym w technice suchej igły widoczny jest prawy profil młodej, ładnej kobiety, emanującej siłą i energią życiową. Austriaczka Margarete Hammerschlag ${ }^{43}$ sposobem autoprezentacji podkreśla swoją przynależność zarówno do sfery Natury ${ }^{44}$, jak i Kultury, postrzeganych najczęściej jako opozycyjne. Na drzeworycie Autoportret (1928), żłobionym szerokim narzędziem, pokazuje siebie z bogactwem elementów charakteryzujących ją jako kobietę silnie zakorzenioną w naturze: z peleryny zarzuconej na staromodną suknię wyrastają drzewka, a doniczka z kwitnącą rośliną, księżyc, kieliszek trzymany w dłoniach i gałązka winogron nawiązują do symboliki płodności, wzrostu, porządku Matki. Na innym drzeworycie, zatytułowanym $W$ loży (autoportret z pieskiem), Hammerschlag ukazuje siebie i mężczyznę w loży teatralnej „patrzących” na widza. Różnicuje przy tym moc spojrzenia, będącego oznaką władzy - ona po prostu patrzy przed siebie, natomiast mężczyzna, uzbrojony w szkła lornetki, wygląda zza kotary podglądając siedzącą tyłem do niego artystkę i (w domyśle) ludzi z naprzeciwka.

Swoistą aurę kobiecego wizerunku wypracowała paryżanka Marie Laurencin. „Jej obrazy przedstawiają świat wyłącznie kobiecy - ją samą, jej przyjaciółki, bajkowe istoty o nieznanych imionach. Te kruche, delikatne postacie bytują w świecie nierzeczywistym, między baśnią, snem a spektaklem jakiegoś nieistniejącego teatru. Otulają je kostiumy lekkie i zwiewne. Z jasnych twarzy marzycielsko patrzą wielkie ciemne oczy”45. Tę sformułowaną przez Marię Poprzęcką trafną syntezę naznaczonej „kobiecą psyche” twórczości Marie Laurencin można odnieść także do tworzonych przez nią litografii i akwafort. W grafikach określonych jednoznacznie jako autoportrety i na portretach innych kobiet artystka powiela własną wyidealizowaną fizjono-

42 Absolwentka ASP w Dusseldorfie, graficzka, nauczycielka rysunku.

43 Uczyła się na kursach F. Cižeka (1911-1917) i w wiedeńskiej Kunstgewerbeschule. Od 1936 r. wraz z mężem, architektem Josefem Bergerem, osiadła w Londynie.

44 W 1917 r. powstał wczesny drzeworyt „Maska” („Maske”); w tytułowej masce, umieszczonej wśród białych kwiatów, gwiazd i tańczącej sylwetki na czarnym tle, można doszukać się rysów twarzy autorki.

45 Maria Poprzęcka, „Marie Laurencin”, w Maria Poprzęcka, Uczta bogiń. Kobiety, sztuka i życie (Warszawa: Agora SA, 2012), 59. 
mię - charakterystyczną trójkątną twarz i przykuwające uwagę oczy o szerokim rozstawie i migdałowym wykroju, z wyrazistymi, czarnymi tęczówkami. Zdaniem Pauli Birnbaum ${ }^{46}$ sposób, w jaki Marie Laurencin ukazywała siebie w malarstwie i grafice, był odmienny od autowizerunku kreowanego przez nią w wierszach i wspomnieniach ${ }^{47}$. Artystka zaakceptowała swój publiczny obraz jako muzy (co zapewniła jej grupa Femmes Artistes Modernes, prasa i odbiorcy), a następnie wyeksploatowała tę skonstruowaną tożsamość przez maskaradę. Jej strategie autoprezentacji były środkiem do promocji własnej niezależności i przyciągnięcia uwagi. Na cykl Eventail („Wachlarz”) wykonany w akwaforcie składa się dziesięć autoportretów ${ }^{48}$. Każda z grafik przywołuje inny nastrój autorki (smutnej, rozbawionej, zamyślonej, zrozpaczonej, rozmarzonej), zmieniają się jej pozy, rekwizyty (wachlarz, kapelusz, kwiat przypięty do sukni, wstążka lub boa na szyi) i elementy otoczenia (gołębie, kotary). Wizerunki bohaterki tych prac - Marie Laurencin o pociągłej twarzy (zazwyczaj ujętej en face lub w trzech czwartych), z zaznaczonymi oczyma i ustami, z rozburzonymi, falistymi włosami - nie zdradzają prawdy o wewnętrznym życiu artystki, nie są próbą poznania samej siebie; są raczej projekcją, wizualnym odpowiednikiem słów jej przyjaciół poetów. Laurencin rozwija, tak jak stopniowo rozkłada się wachlarz, opowieść o swych emocjach i ulotnych nastrojach. Sprawnie posługuje się bardzo oszczędnymi środkami: pojedynczą linią i zespołami linii o zróżnicowanym zagęszczeniu i różnym czasie trawienia, gęstym, krzyżującym się szrafowaniem tworzącym niemal jednolitą płaszczyznę czerni. Autoportrety te cechuje lekkość, niedopowiedzenie, niedookreślenie - dużą rolę w uzyskaniu tego efektu odgrywa neutralne tło; w części prac „pustka” bieli dominuje nad postacią.

Kobiety, świat kobiecych zajęć i rozrywek obecne są także w grafikach Mily Possoz (1888-1967), Portugalki tworzącej w Paryżu w latach 1922-1937. Na Autoportrecie ${ }^{49}$ (ręcznie kolorowana akwaforta) wykonanym delikatną, słabą trawioną kreską ukazała siebie jako dziewczynę wpatrzoną w kartkę trzymaną w dłoni, z ołówkiem w drugiej ręce. Praca ta nosi cechy lekkiego, niepozbawionego dekoracyjnych elementów szkicu, bardzo oszczędnie pod-

46 Birnbaum, Women Artists, 110-111.

47 Jest autorką wierszy i opublikowanych pod koniec życia wspomnień Carnets de Nuits.

48 Portfolio wydane w 1922 r. zawiera wiersze o artystce napisane przez jej przyjaciół (m.in. Rogera Allarda, André Bretona, Francisa Carco, Maxa Jacoba, Jeana Pellerin, André Salmona); poszczególne tytuły wierszy i nazwiska autorów zostały umieszczone pod każdym z autoportretów Laurencin.

49 Niedatowany, ze ślepo tłoczoną pieczątką wydawcy Marcela Guiota. 
kolorowanego, choć poszczególne odbitki różnią się intensywnością barwy. Artystka, podobnie jak Laurencin, podkreśla w nim swoją dziewczęcość i delikatne rysy twarzy, dokonując charakterystycznych dla siebie stylizacji i uproszczeń.

Od subtelnych formalnie i nastrojowych autoportretów-masek Marie Laurencin, pozbawionych głębszej refleksji nad tożsamością człowieka, kobiety i artystki, różni się wyrazisty wizerunek własny węgierskiej graficzki Hanny Dallos ${ }^{50}$ (1907-1945) - drzeworyt Autoportret z 1930 roku. Artystka ukazała siebie na wprost, w zwykłym stroju „roboczym” (ciemny beret, fartuch, koszula z kołnierzem). Charakterystyczne uczesanie z przedziałkiem pośrodku i dwoma warkoczami upiętymi przy uszach znane jest z kilku fotografii Dallos z okresu, w którym wykonała tę pracę. Najciekawsze jest jednak to, że przedstawiła siebie w trakcie opracowywania drzeworytniczego klocka (wycina w nim swój monogram). Jednoznacznie więc określa się jako graficzka, a zaświadcza o tym spojrzeniem, skierowanym wprost ku odbiorcy. Tożsamość obrazowanej czynności z medium, które artystka wybrała do wykonania autoportretu, odgrywa w tej wypowiedzi ogromną rolę - jest potwierdzeniem potrzeby zdefiniowania swej profesji, a zarazem pasji artystki-drzeworytniczki.

Niniejszy przegląd autoportretów artystek z kilku krajów europejskich i Stanów Zjednoczonych, wykonanych w większości w latach dwudziestych i trzydziestych XX wieku, nie wyczerpuje tematu. Daje jednak pewien pogląd na specyfikę tego rodzaju autoprezentacji i odmienności podejścia poszczególnych twórczyń, niezależnie od narodowości, chociaż jako wspólną cechę Amerykanek można wskazać dużą częstotliwość przedstawiania siebie jako artystki (w tym graficzki, rysowniczki). Oprócz powracającego pytania o przyczynę niewielkiej liczby wizerunków własnych rodzimych twórczyń powstaje kolejne: czy ich sposoby kreowania siebie lub „opowiadania o sobie” wpisują się w sposoby autoekspresji zagranicznych artystek, czy są odmienne, a jeśli

50 Graficzka, ilustratorka książek, autorka plakatów. Studiowała w Szkole Sztuki Użytkowej w Budapeszcie. Wykonała cykl drzeworytów ilustrujących modlitwę Ojcze nasz (Mi Atyank). Wraz z mężem Josephem Kreutzerem, projektantem mebli, i przyjaciółką Gittą Mallász, graficzką, założyli studio projektowe; w swych pracach łączyli rodzime motywy folklorystyczne ze stylem art déco. Transcendentne doświadczenie artystki z czasów II wojny światowej (1943-1944), tzw. anielskie przesłanie, zostało spisane przez Gittę Mallász i Lili Strausz i wydane w 1976 r. we Francji jako Dialogues avec l’Ange („Rozmowy z aniołami”), następnie przetłumaczone na inne języki. Hanna Dallos zginęła w czasie transportu do obozu koncentracyjnego. 
tak, to w jakim zakresie? Komorowska, Goryńska, Giedroyć-Wawrzynowicz każda wykonała po kilka autoportretów w technikach grafiki warsztatowej, trudno jednak mówić o jakiejś częstotliwości lub regularności powstawania tych prac. W tym sensie działalność polskich artystek nie była zbieżna z praktyką Margaret Kubickiej bądź Käthe Kollwitz, które tworzenie wizerunków własnych czy to w rysunku, czy w grafice traktowały jako zapis chwili, upływającego czasu, utrwalania za pomocą wyglądu i rysujących się na twarzy emocji ważnych momentów. W autoportretach polskich graficzek odnajdziemy zaledwie epizody, pojedyncze karty z życia, które jednak wiele mówią o nich samych i ich motywacji do tworzenia własnych podobizn. Wanda Komorowska utrwalając swój wizerunek (zazwyczaj w popiersiu) nie odtwarzała wyłącznie rysów twarzy; podejmowała z odbiorcą swoistą grę: zagadkowym uśmiechem, tajemniczym gestem lub motywem o symbolicznym znaczeniu ${ }^{51}$. Autoportrety Wiktorii Goryńskiej były manifestacją, odzwierciedleniem jej postawy życiowej i priorytetów w danym okresie. Artystka jawi się nam chronologicznie - najpierw jako młoda, pełna wdzięku kobieta (prywatny aspekt autoportretu w stroju domowym), następnie jako organizatorka i działaczka, dla której sprawy osobiste schodzą na dalszy plan, ważniejsza staje się służba obywatelska, a także florecistka, która realizuje się w rywalizacji sportowej fair play. Wizerunki własne Janiny Róży Giedroyć-Wawrzynowicz w pewnym stopniu ujawniają jej marzenia i tęsknoty, wyobrażenia o idealnym „ja” ${ }^{52}$, ale są też świadectwem codziennego stawiania czoła rzeczywistości w roli artystki, żony i matki. Giedroyć-Wawrzynowicz jest przy tym autorką jedynego w polskiej grafice tego czasu zawodowego autoportretu artystki. Żadna z polskich graficzek nie idealizuje przesadnie własnej fizjonomii, nie kreuje swej legendy za życia, w sposób, w jaki czyniła to np. Marie Laurencin, ale też omówione tu ich prace nie zdradzają cech karykatury (jak $\mathrm{u}$ Amerykanek) ani nie zostały poddane pełnej ekspresji deformacji (jak u artystek niemieckich). Autoportrety polskich twórczyń są realistyczne, bardzo dobre warsztatowo. Są świadectwem zindywidualizowanego przekazu adresowanego do odbiorcy (w tym do bliskich osób), ale niekiedy „wiadomością” skierowaną do siebie. Jednak wyjątkiem jest autoportret zawodowy, którym

51 Scena rodzajowa ze szkieletami w tle autoportretu; akwaforta ze zbiorów Muzeum Narodowego w Krakowie, odbita na odwrocie innej kompozycji artystki.

$52 \mathrm{Na}$ autoportretach graficznych i malarskich stylizuje swą fryzurę i nakrycia głowy (chusty) lub cienkie opaski zdobiące czoło, aby upodobnić się do renesansowej damy lub muzy prerafaelitów. 
autorka potwierdza świadomość swej profesji - nie tylko jako artystki, ale w węższym zakresie: jako graficzki ${ }^{53}$, co dla Amerykanek było ważnym aspektem tożsamości.

Dlaczego polskie graficzki tworzące w okresie międzywojennym pozostawiły tak niewiele autoportretów, chociaż artystki z innych krajów tworzyły je (w tym samym czasie) w różnych technikach graficznych znacznie częściej, a polscy graficy wykonali w sumie kilkadziesiąt wizerunków własnych? Wydaje się, że przyczyn należałoby szukać w sferze pozaartystycznej - ich źródłem były raczej sposób myślenia oraz wzorce kobiecych ról i zachowań przekazywane w polskich rodzinach od pokoleń ${ }^{54}$. Większość polskich artystek, dysponując znakomitym warsztatem, nie wychodziła poza najczęściej podejmowaną wówczas w polskiej grafice tematykę pejzażu i architektury. Swoje „ja” ukrywały za umiejętnością tworzenia w większości technik graficznych, których warsztat świetnie opanowały, a dzięki perfekcji wykonania zyskiwały aprobatę (oraz, co ważne, możliwość sprzedaży swych prac), tworząc tak jak mężczyźni i przyjmując perspektywę męskiego obserwatora. Wydaje się, że były w pełni świadome wartości swej pracy twórczej, intelektu i umiejętności, ale nie doceniały jeszcze swego znaczenia i siły oddziaływania jako artystki-graficzki. W tym upatrywałabym przyczyn niechęci bądź braku potrzeby eksponowania w grafice własnego wizerunku zawodowego. Jednocześnie trzeba odrzucić wcześniejsze założenie odnośnie do wyrównania szans (na etapie kształcenia) kobiet i mężczyzn uprawiających grafikę, które miało wzmocnić status twórczyń i utwierdzić je w przekonaniu, że nie muszą wobec siebie i świata potwierdzać, że są artystkami.

Należy odnotować, że po 1945 roku sytuacja się zmieniła - polskie graficzki, które były aktywne już w okresie międzywojnia i nie wykonały wówczas autoportretu, jako dojrzałe i starsze kobiety znacznie częściej siebie portretowały. Swoje wizerunki pozostawiły m.in. Krystyna Wróblewska (drze-

53 W Polsce dopiero w 1950 r. Krystyna Wróblewska wykonała drzeworytniczy Autoportret z rylcem i klockiem, odnosząc się nie tylko do dyscypliny, ale też obrazując poszukiwanie inspiracji i etapy procesu tworzenia. W tle pierwszoplanowego ujęcia własnej twarzy Wróblewska ukazała siebie wędrującą z plecakiem w góry, muzyka z instrumentami, a po przeciwnej stronie siebie przy biurku opracowującą matrycę.

54 Rolą kobiety była opieka nad członkami rodziny, troska o codzienny byt, wreszcie zastąpienie i przejęcie funkcji męża podczas jego nieobecności (jeśli zginął lub walczył w powstaniu, na froncie). Jeśli nawet kobieta nie założyła własnej rodziny, miała obowiązki wobec rodziców i krewnych. Mechanizmy te wyjaśniła Sławomira Walczewska, Damy, rycerze i feministki. Kobiecy dyskurs emancypacyjny w Polsce (Kraków: eFKa, 2000). 
woryty Autoportret i Autoportret I, 1950; Autoportret II, 1956; Twarz kobiety, 1957; Głowa, 1957; Skupiona, 1959), Bogna Krasnodębska-Gardowska (drzeworyt Autoportret, 1950), Maria Hiszpańska-Neumann (suchoryt, 1947). Autoportret wykonany w technikach grafiki artystycznej zyskał nowy wyraz w drugiej połowie XX wieku, a graficzki, pokazując w nim skalę możliwości swojego warsztatu, zagłębiły się między innymi w problematykę kobiecej tożsamości, pamięci i przemijania, o czym warto się przekonać obcując np. z pracami Krystyny Piotrowskiej ${ }^{55}$.

\section{Bibliografia}

\section{Druki i opracowania}

Artystki polskie, Muzeum Narodowe w Warszawie, koncepcja, wstęp i red.

Agnieszka Morawińska. Warszawa: Muzeum Narodowe, 1991.

Birnbaum, Paula. "A Changing Self-Image". W Women Artists in Interwar France: Framing Femininities. Farnham-Burlington: Routledge, 2011.

Borowy, Wacław. „Wspomnienie o Wiktorii Goryńskiej”. Tygodnik Powszechny, 21-28 maja, 1950, 7.

Borzello, Frances. A World of Our Own. Women as Artists. London: Thames \& Hudson, 2000.

Borzello, Frances. Seeing Ourselves: Women's Self-Portraits. London: Thames \& Hudson,1998.

Dialog czarno na białym. Grafika polska i węgierska 1918-1939, Muzeum

Narodowe w Warszawie-Magyar Nemzeti Galéria w Budapeszcie, tekst Anna Manicka i Katalin Bakos. Warszawa: Muzeum Narodowe, 2009.

Field, Richard S., i Ruth E. Fine. A Graphic Muse: Prints by Contemporary American Women. New York: Hudson Hills, 1987.

Fruhauf, Alina, i Erwin P. Vollmer. Making Faces. Memoirs of a Caricaturist AlineFruhauf. Santa Barbara: John Daniel \& Co, 1990.

Głuchowska, Lidia. Avantgarde und Liebe. Margarete und Stanislaw Kubicki 1910-1945. Serie: Humboldt-SchriftenzurKunst- und Bildgeschichte. T. 4. Berlin: Gebr. Mann, 2007.

Goryńska, Wiktoria Julia. "Contemporary Wood-Engraving in Poland”. The Print Collector's Quarterly 22 (1935): 325-347.

Grońska, Maria. Nowoczesny drzewory tpolski. Wrocław: Ossolineum, 1971.

55 Autorka podwójnych portretów, w których zestawiała własny wizerunek z autoportretami wybitnych artystów (m.in. Vincenta van Gogha i Fridy Kahlo). 
Harvey-Lee, Elisabeth. Mistress of the Graphic Arts: Famous and Forgotten Women Printmakers, c. 1550 - c. 1950. (Dealer's Catalogue). Oxford: Elisabeth Harvey-Lee, 1995. Harvey-Lee, Elisabeth. The Artist Mirrored. A Selection of Artists' Printed Portraits \& Self-Portraits. North Aston: Elisabeth Harvey-Lee, 2002.

Jaffe, Patricia. Women Engravers. London: Virago, 1988.

Kearns, Martha. Käthe Kollwitz: Woman and Artist. New York: Feminist Press, 1976.

Kossowska, Irena. „Aporia: zwielokrotnione wizerunki, sparafrazowane obrazy”. Konteksty 1-2 (2012): 285-297.

Kossowska, Irena. Narodziny polskiej grafiki artystycznej 1897-1917. Kraków: Universitas, 2000.

Kowalczykowa, Alina. Świadectwo autoportretu. Warszawa: Biblioteka WWSH, Fundacja Humanistyczna, IBL PAN, 2008.

Kulpińska, Katarzyna. „Autoportret w grafice artystów grupy Bunt”. W Bunt a tradycje grafiki w Polsce i Niemczech, Bydgoszcz: Muzeum Okręgowe, 2015.

Kulpińska, Katarzyna. Matryce, odbitki - ślady kobiet. Polskie graficzki i ich twórczość $w$ dwudziestoleciu międzywojennym. Toruń: Wydawnictwo Naukowe UMK, 2017.

Lejeune, Philippe. „Patrząc na autoportret”. W Philippe Lejeune, Wariacje na temat pewnego paktu. O autobiografii. Tłumaczenie Regina Lubas-Bartoszyńska. Kraków: Universitas, 2001.

Luba, Iwona. Dialog nowoczesności z tradycją. Warszawa: Neriton, 2004.

Margarete Hammerchlag, tekst Raymond Berger. Wien: Galerie bei der Oper, GaleriaWalfischgasse Rudolf Minibacher, 2012.

Meskimmon, Marsha. The Art of Reflection. Women Artists'Self-Portraiture in the Twentieth Century. New York: Columbia University Press, 1996.

Nagel, Otto. Die Selbstbildnisse der Käthe Kollwitz. Berlin: Henschelverlag, 1965.

Owens, Clive. „Dyskurs Innych: feministki i postmodernizm”. Tłumaczenie Małgorzata Sugiera. W Postmodernizm. Antologia przekładów, oprac. i wstęp Ryszard Nycz. Kraków: Wydawnictwo Baran i Suszczyński, 1997.

Poprzęcka, Maria. „Marie Laurencin”. W Uczta bogiń. Kobiety, sztuka i życie, 44-61. Warszawa: Agora SA, 2012.

Rideal, Liz. Mirror, Mirror. Self-Portraits by Women Artists (with Essays by Whitney Chadwick and Frances Borzello). London: Watson-Guptill Publications, 2002.

Rylska, Irena. Katalog zbiorów Gabinetu Grafiki. T. 1 Grafika polska w latach 1901-1939. Wrocław: Muzeum Narodowe, 1983.

Samotyhowa, Nela [Aniela]. „Wiktoria Goryńska. (Portret podwójny)”. Praca Obywatelska 22 (1934): 14-16.

Sosnowska, Joanna. Poza kanonem. Sztuka polskich artystek 1880-1939. Warszawa: Instytut Sztuki PAN, 2003.

Stacewicz, Joanna. „Mała rewolucja i wielkie serce. Kontrastowo o Janinie Róży Giedroyć-Wawrzynowicz". Aspiracje, wiosna (2009): 48-53.

Stawska, Regina. „Graficzka nieznana”. Art\&Business 10 (2008): 66-69. 
Stawska, Regina. „Między rylcem a floretem”. Art\&Business 11 (2005): 28-31.

Sztuka wszędzie. Akademia Sztuk Pięknych w Warszawie 1904-1944, koncepcja Maryla Sitkowska, red. Jolanta Gola, Maryla Sitkowska i Agnieszka Szewczyk. Warszawa: ASP, 2012.

Taylor, Barbara Ann. “Wood Engraving by Women Artists”. Oxford Art Journal 3 (1980) 1: 79-82.

Unseen Hands: Women Printers, Binders, and Book-Designers, red. Rebecca Warren Davidson. Princeton University Library, Graphic Arts Collection, 2005. on-line exhibition. http://ibweb2.princeton.edu/rbsc2/ga/unseenhands/ occupation.html\#5. Dostęp 5 września 2016.

Walczewska, Sławomira. Damy, rycerze i feministki. Kobiecy dyskurs emancypacyjny w Polsce. Kraków: eFKa, 2000.

Wallis, Mieczysław. „Autoportrety artystek”. Wiedza i Życie 10 (1949): 916.

Wallis, Mieczysław. Autoportret. Warszawa: WAiF, 1964.

Wallis, Mieczysław. Autoportrety artystów polskich. Warszawa: WAiF, 1966.

Wiktoria Goryńska 1902-1945: katalog grafiki, oprac. Maryla Sitkowska. Warszawa: Muzeum Narodowe, 1977.

Wydobyć z zapomnienia, red. Jacek Bochiński i Janusz Plapis, tekst Róża Wawrzynowicz-Bilip. Warszawa: Muzeum Historyczne st.m. Warszawy [2008].

Wyprawa w dwudziestolecie, red. Katarzyna Nowakowska-Sito. Warszawa: Muzeum Narodowe, 2008.

Zientara, Maria. „Artystki polskie i ich sztuka w latach 1900-1939. Cz. IV Przedstawicielki realizmu”. Krzysztofory. Zeszyty Naukowe Muzeum Historycznego Miasta Krakowa 29 (2011), 327-362. 


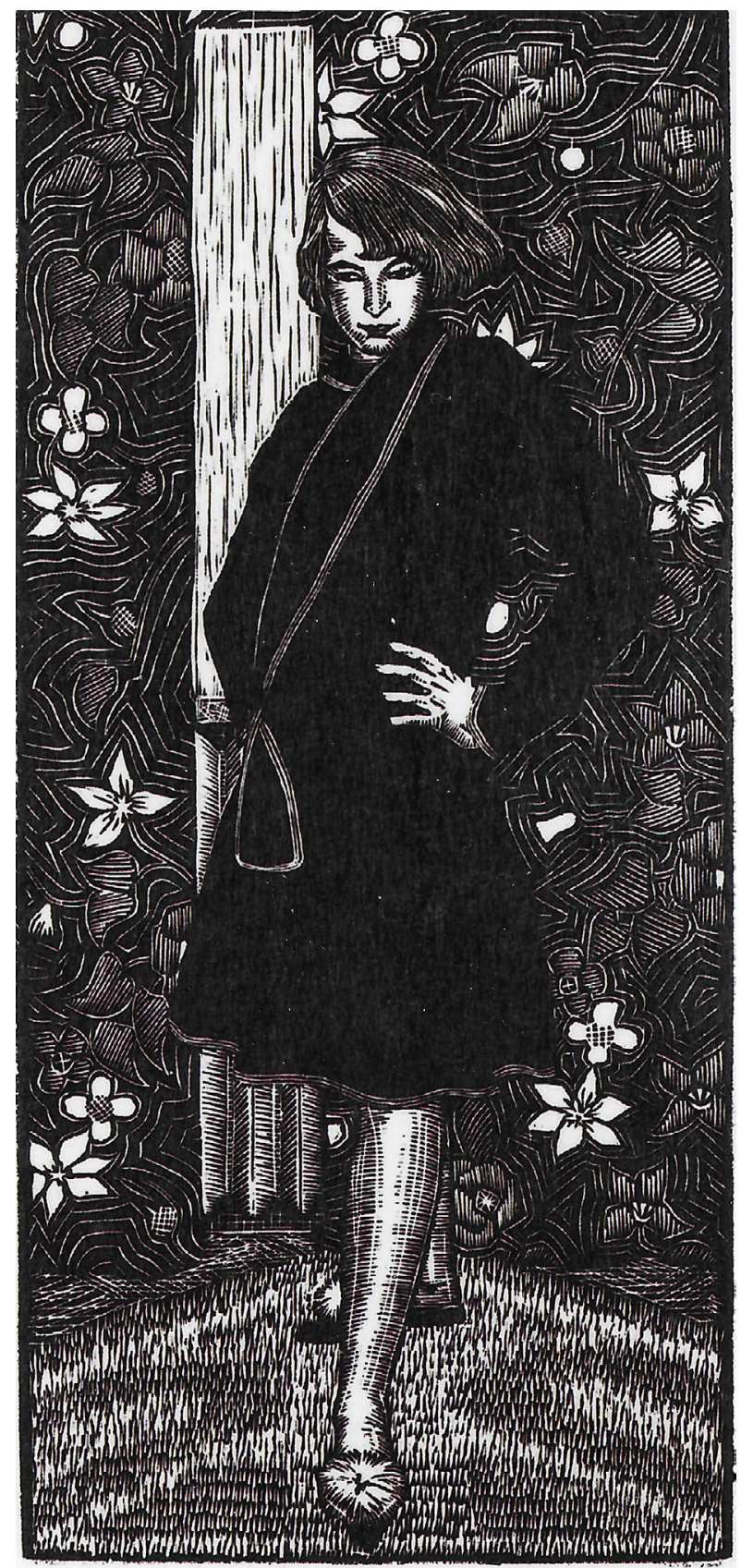

1079

1. Wiktoria Goryńska, Autoportret w stroju domowym, drzeworyt, 237 x 142, 1929, Biblioteka Uniwersytetu Warszawskiego, Inw. GR 1303. 


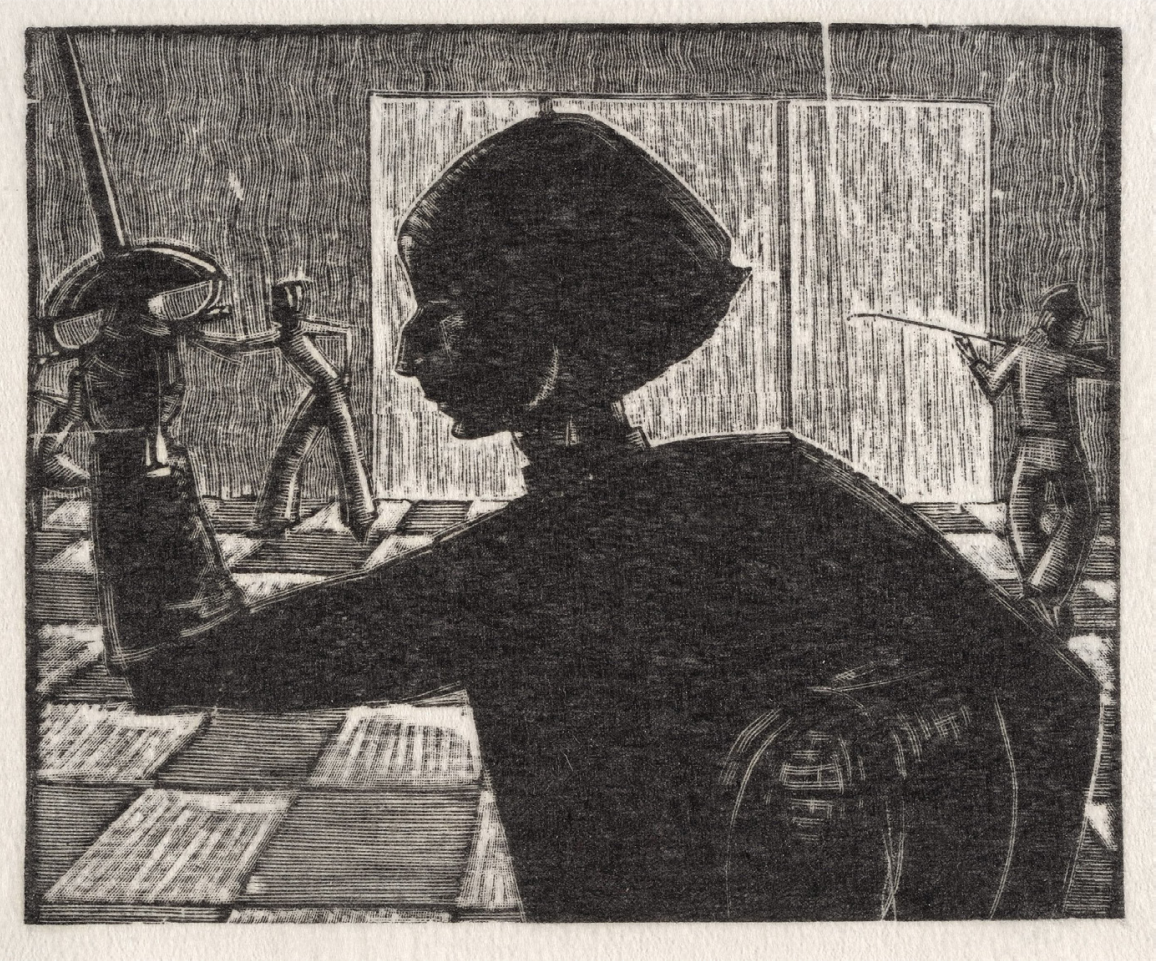

2. Wiktoria Goryńska, Autoportret jako florecistka, drzeworyt, bib., 92 x 111, ok. 1932-1935, Muzeum Narodowe w Warszawie, Gr.W.4735/1. Fot. Archiwum Foto MNW 


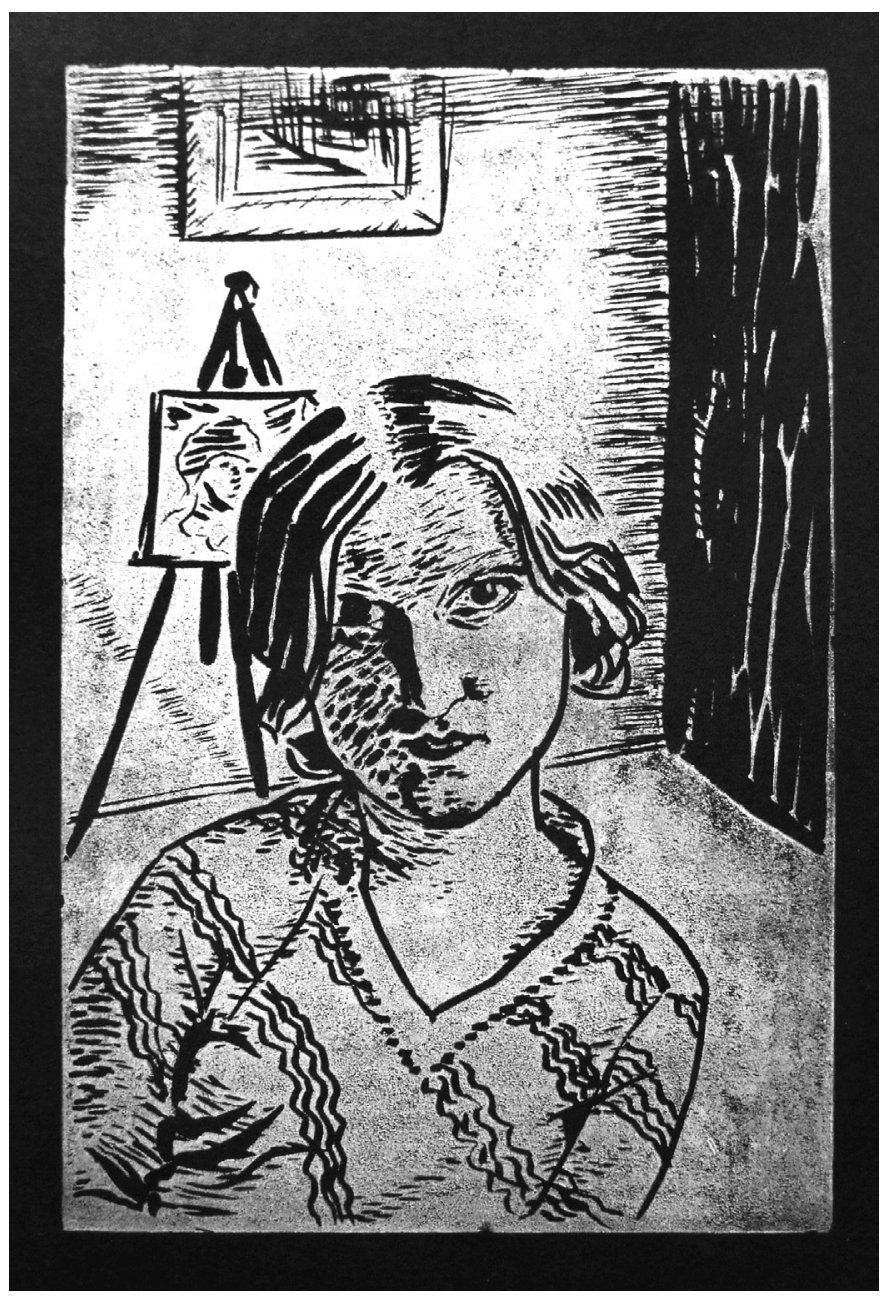

3. Janina Giedroyć-Wawrzynowicz, Autoportret ze sztalugami, drzeworyt, 203 x 127, ok. 1933, własność prywatna. Fot. Katarzyna Kulpińska 


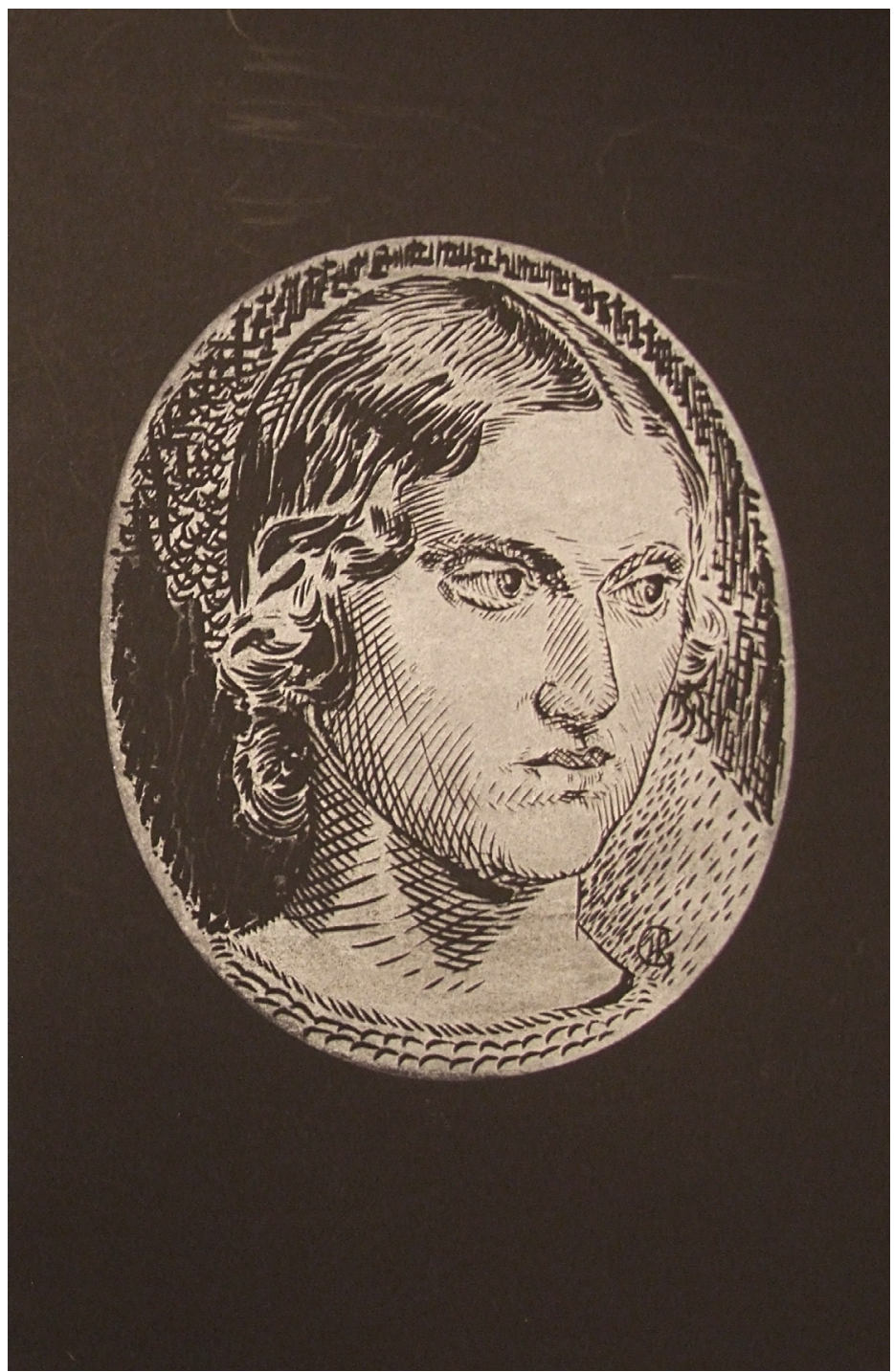

4. Janina Giedroyć-Wawrzynowicz, Autoportret w owalu, drzeworyt, ok. 1932, własność prywatna. Fot. Katarzyna Kulpińska 


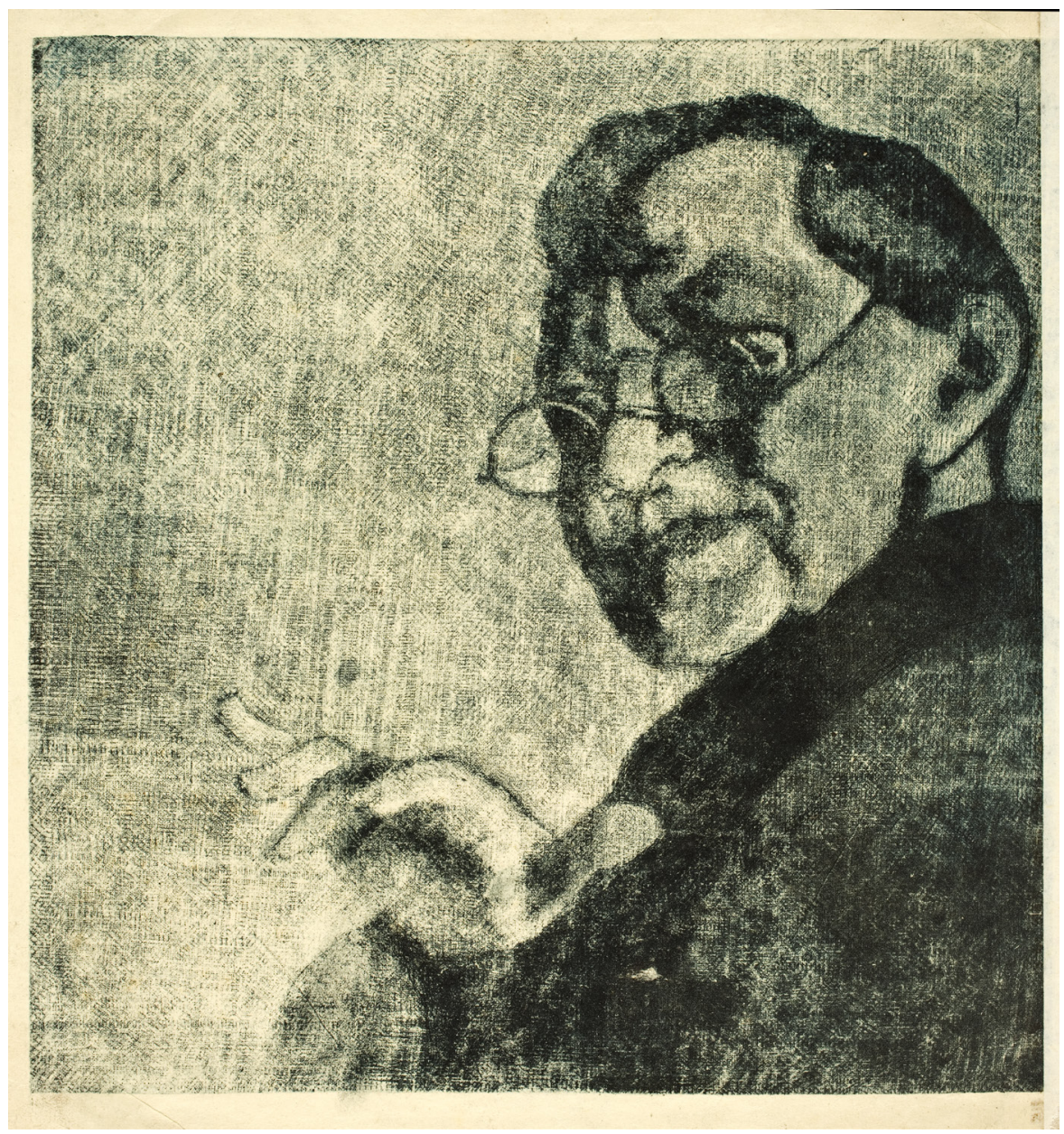

5. Wanda Komorowska, Autoportret II, mezzotinta, Muzeum Narodowe we Wrocławiu, VII-4572. Fot. A. Podstawka 